\title{
START-UP ADJUSTMENT OF A PLUG-FLOW DIGESTER FOR CASSAVA WASTEWATER (MANIPUEIRA) TREATMENT
}

\author{
Maria Magdalena Ferreira Ribas ${ }^{1}$; Ana Cláudia Barana ${ }^{2 *}$ \\ ${ }^{1}$ UNESP - Centro de Raízes e Amidos Tropicais - C.P. 237, 18601-970 - Botucatu, SP - Brasil. \\ ${ }^{2} U E P G$ - Depto. de Engenharia de Alimentos - Av. Carlos Cavalcanti, 4748 - 84030-900 - Ponta Grossa, \\ PR - Brasil. \\ *Corresponding author <anabarana@yahoo.com>
}

\begin{abstract}
Manipueira, wastewater of cassava (Manihot esculenta) processing, can be treated by anaerobic biodigestion. To study the start-up process of a plug-flow digester for manipueira treatment, this work consisted of two stages: gradual decrease of the hydraulic retention time (HRT) to the preset time of 4 days or maintaining a fixed HRT of 4 days with gradual increase of the substrate concentration. A digester of $1980 \mathrm{~mL}$ capacity was opperated, at constant temperature $\left(32 \pm 1^{\circ} \mathrm{C}\right)$, with substrate $\mathrm{pH}$ corrected between 5.5 and 6.0. The first stage had durations of 16.6; 13.6; 11.6; and 9.6 days and the organic loads were 3.1; 2.0; 2.3; and 2.9 $\mathrm{COD} \mathrm{L}^{-1} \mathrm{~d}^{-1}$, (chemical oxigen demand) respectively. The second stage was characterized by a fixed HRT (4 days) and organic loads of $0.48 ; 0.86 ; 1.65$; and $2.46 \mathrm{~g} \mathrm{COD} \mathrm{L}^{-1} \mathrm{~d}^{-1}$. Total solids (TS), volatile solids (VS), COD, alkalinity and volatile acidity were determined in the substrate and in the effluent. During the first stage, the HRT of 9.6 days and organic load of $2.9 \mathrm{~g} \mathrm{COD} \mathrm{L}^{-1} \mathrm{~d}^{-1}$ resulted in the best performence; reductions in COD, total and volatile solids were 60, 44 and 60\%, respectively. During the second stage, with a 4-day HRT, the best results were achieved with the $0.86 \mathrm{~g} \mathrm{COD} \mathrm{L}^{-1} \mathrm{~d}^{-1}$ organic load, which provided reductions in COD, total and volatile solids of 71, 58 and 79\%, respectively. The start-up of the plug-flow digester for manipueira treatment can be made by gradually by decreasing the HRT, or fixing HRT and increasing substrate concentration.
\end{abstract}

Key words: cassava, anaerobic, effluent, biodigestion

\section{PROCESSO DE PARTIDA DE UM BIODIGESTOR DO TIPO PLUG-FLOW PARA TRATAMENTO DA MANIPUEIRA}

\begin{abstract}
RESUMO: Um dos resíduos gerados no processamento da mandioca (Manihot esculenta) é a manipueira, passível de tratamento por biodigestão anaeróbia. Este trabalho objetivou estudar o processo de partida de um biodigestor tipo plug-flow, tratando manipueira de duas maneiras: diminuindo-se gradativamente o tempo de retenção hidráulica (TRH) até se chegar ao tempo pré-estabelecido, quatro dias; ou mantendo-se o TRH fixo em quatro dias e aumentando-se gradativamente a concentração do afluente. O biodigestor, com capacidade $1980 \mathrm{~mL}$, foi mantido a temperatura de $32^{\circ} \mathrm{C} \pm 1$. Empregou-se como substrato manipueira e ajustou-se o $\mathrm{pH}$ entre 5,5 e 6,0. A primeira etapa foi caracterizada empregando-se TRH de 16,6; 13,6; 11,6 e 9,6 dias e 3,1;2,0;2,3 e 2,9 g DQO L $\mathrm{g}^{-1}$ de carga orgânica, respectivamente. Na segunda etapa mantevese TRH fixo, 4 dias, porém cargas orgânicas de $0,48,0,86,1,65$ e 2,46 g DQO L $\mathrm{g}^{-1} \mathrm{~d}^{-1}$. Determinaram-se no afluente e efluente, sólidos totais (ST) e sólidos voláteis (SV), demanda química de oxigênio (DQO), alcalinidade e acidez volátil. Na primeira etapa, melhores resultados foram observados trabalhando com TRH 9,6 dias e carga orgânica 2,9 g DQO L ${ }^{-1} \mathrm{~d}^{-1}$, quando houve redução de DQO, ST e SV de $60 \%, 44 \%$ e $60 \%$, respectivamente. Na segunda etapa o TRH de 4 dias apresentou melhores resultados empregando-se carga orgânica de $0,86 \mathrm{~g}$ DQO L $^{-1} \mathrm{~d}^{-1}$, houve redução de $71 \%, 58 \%$ e $79 \%$ de DQO, ST e SV, respectivamente. A partida do biodigestor plug-flow tratando manipueira, pode ser realizada tanto diminuindo-se o TRH, quanto mantendo-o fixo e aumentado-se a concentração do afluente.

Palavras-chave: mandioca, anaeróbio, efluente, biodigestão
\end{abstract}

\section{INTRODUCTION}

The types of waste materials generated by cassava (Manihot esculenta, Crantz) processing plants require solutions tailored to the social and economic level of the industries. When low-cost solutions are not available, effluents are usually dumped into rivers or on the soil, causing serious environmental impact. The liquid residue, technically called manipueira, contains minerals (nitrogen, carbon, phosphorus, potassium, calcium, magnesium, sulfur, zinc, manganese, copper, iron and sodium) which, after anaerobic biodigestion, can still be used for fertirrigation, since the digestion process does not substantially decrease the mineral content (Barana, 2000). 
Many attempts have been made to aggregate economic value to the manipueira by considering its utilization as a fertilizer (Ponte, 2001), herbicide (Fioretto, 1985), insecticide (Ponte et al., 1992), nematicide (Ponte \& Franco, 1983; Sena \& Ponte, 1982), biosurfactant (Santos et al., 2000) or substrate for microorganism growth (Wosiacki et al., 1994). The production of biogas (Lacerda, 1991; Fernandes Jr., 1989; Fernandes Jr., 1995; Barana, 1996; Barana, 2000), single-cell oil (Wosiacki et al., 1994), microbial protein (Menezes, 1994) and recently, aromas (Damasceno, 1998) can be cited as examples of its use.

The plug flow reactor is a simplified digester constructed of inexpensive materials, and operates in a very simple manner since there is no agitation (Kubiak \& Dubuis, 1985). In a plug flow digester the substrate moves along the reactor without interacting with the substrate that enters the system previously or will pass through at a later time, working as a multi-stage, single-compartment reactor (Armenante, 1993). The basic assumption in a plug flow reactor is that the fluid is ideally mixed laterally and not mixed longitudinally.

One of the main problems of starting an anaerobic digester consists in adapting the microorganisms to the effluent. Once the biomass is stabilized, the reactor is also stabilized. It is, therefore, recommended that the residue is gradually introduced until a desired load is reached (Stronach et al., 1987). During the start-up period the growth of anaerobic sludge can benefit from the application of organic loads with high dilution rates. This is the best way of ensuring the stability of the process (Lettinga \& Hulshoff Pol, 1991).

\section{MATERIAL AND METHODS}

Substrate - Manipueira from different lots was collected

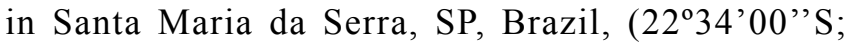
$\left.48^{\circ} 09^{\prime} 36^{\prime \prime} \mathrm{W}\right)$, and in Tibagi, PR, Brazil, (24\%30'34'S; $50^{\circ} 24$ ' $\left.55^{\prime \prime} \mathrm{W}\right)$. The most frequent cassava cultivars were: Olho Junto, Fibra and IAC 13. After the manipueira was collected, remaining starch was allowed to settle for two hours, and samples were taken for physico-chemical characterization analyses. The supernatant was transferred to $5 \mathrm{~L}$ plastic containers and frozen. The $\mathrm{pH}$ of the substrate was corrected daily, before being injected into the reactor, with $\mathrm{NaOH} 50 \%(\mathrm{w} / \mathrm{v})$ solution; $\mathrm{pH}$ was kept between 5.5 and 6.0, ideal for acidogenic bacteria, which would concentrate predominantly at the base of the reactor, i.e., at the substrate inlet (Souza, 1984).

Plug flow digester - $1980 \mathrm{~mL}$ net capacity, consisting of two polyvinyl chloride concentric tubes, one $11 \mathrm{~cm}$ in diameter and $32 \mathrm{~cm}$ in height and the other $15 \mathrm{~cm}$ in diameter and $35 \mathrm{~cm}$ in height, arranged vertically (Figure 1). The smaller diameter tube was filled with hoses

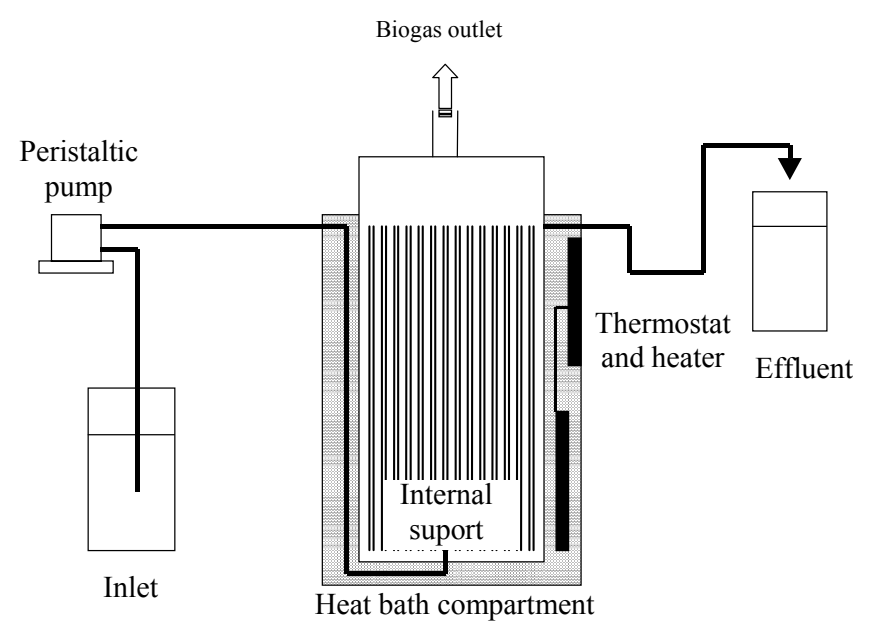

Figure 1 - Schematics of plug flow reactor for manipueira treatment.

having an internal diameter of $0.5 \mathrm{~cm}$, and $0.7 \mathrm{~cm}$ externally, arranged vertically. The space between the 11 and $15 \mathrm{~cm}$ tubes was filled with water maintained at a constant temperature $\left(32^{\circ} \mathrm{C} \pm 1\right)$ by a thermostat-controlled heater.

Experiment - the digester was daily and intermittently fed by a peristaltic pump connected to a timer. The substrate entered the column at its bottom and the outlet was in the upper part of the system. No physical separation of the acidogenic and methanogenic stages occurred; both took place in a single compartment. The top of the reactor had an outlet for biogas. The start-up adjustment phase was divided into two stages:

First stage - hydraulic retention time (HRT) values of $16.6 ; 13.6 ; 11.6$ and 9.7 days were adopted, and the inlet flow was gradually raised from 119, 145, 170 to 205 $\mathrm{mL}$ day $^{-1}$. The organic load utilized was $3.1 ; 2.0 ; 2.3$ and $2.9 \mathrm{~g} \mathrm{COD} \mathrm{L}^{-1} \mathrm{~d}^{-1}$, (chemical oxigen demand per liter day) respectively for each HRT (Table 1). Total and volatile solids analyses were performed for the substrate and the effluent, (\%), COD, $\left(\mathrm{g} \mathrm{L}^{-1} \mathrm{O}_{2}\right)$, alkalinity, $\left(\mathrm{mg} \mathrm{CaCO}_{3} \mathrm{~L}^{-1}\right)$, and volatile acidity, $\left(\mathrm{mg} \mathrm{CH}_{3} \mathrm{COOHL}^{-1}\right)$, in addition to $\mathrm{pH}$ and volume measurements.

Second stage - The HRT was kept at a fixed value of four days with a constant flow of $495 \mathrm{~mL} \mathrm{day}^{-1}$. The substrate concentration was raised every four HRTs (16 days). The loads in this stage were: $0.48 ; 0.86 ; 1.65$ and $2.46 \mathrm{~g} \mathrm{COD}$ $\mathrm{L}^{-1} \mathrm{~d}^{-1}$ (Table 1). Data from the first HRT for each applied load were discarded to eliminate interferences from the previous load, and data from the other three HRTs were utilized at the start-up study analysis.

Inoculation - The reactor was started without the use of inoculum and after 45 days a constant decline of the $\mathrm{pH}$ of the effluent was observed. Inoculation with fresh bovine manure was performed in an attempt to enrich the sub- 
Table 1 - Values for hydraulic retention time (HRT), flow, chemical oxygen demand (COD), organic loads, and total (TS) and volatile solids (VS) of the substrate utilized in the first and second stages of the experiment.

\begin{tabular}{|c|c|c|c|c|c|}
\hline \multicolumn{6}{|c|}{ First stage } \\
\hline HRT $^{*}$ & Flow & COD & $\begin{array}{l}\text { Organic } \\
\text { load** }\end{array}$ & $\mathrm{TS}$ & VS \\
\hline days & $\mathrm{mL}$ day $^{-1}$ & $\mathrm{~g} \mathrm{~L}^{-1} \mathrm{O}_{2}$ & $\mathrm{~g} \mathrm{COD} \mathrm{L}^{-1} \mathrm{~d}^{-1}$ & -- & $\%--$ \\
\hline 16.6 & 119 & 51.5 & 3.1 & 2.3 & 1.6 \\
\hline 13.6 & 145 & 27.2 & 2.0 & 4.2 & 3.7 \\
\hline 11.6 & 170 & 26.5 & 2.3 & 4.8 & 4.3 \\
\hline 9.7 & 205 & 28.4 & 2.9 & 4.8 & 4.3 \\
\hline \multicolumn{6}{|c|}{ Second stage } \\
\hline 4 & 495 & 1.90 & 0.48 & 0.27 & 0.24 \\
\hline 4 & 495 & 3.43 & 0.86 & 0.35 & 0.32 \\
\hline 4 & 495 & 6.60 & 1.65 & 0.53 & 0.48 \\
\hline 4 & 495 & 9.84 & 2.46 & 0.66 & 0.60 \\
\hline
\end{tabular}

*HRT: reactor volume/inlet flow. **Organic load: COD/HRT.

strate with methanobacteria, but the outlet $\mathrm{pH}$ remained near 4.5. The digester was then left for 15 days without feeding to allow methanobacteria time enough to consume the organic acids (Nogueira, 1986).

Analyses - To monitor treatment efficiency during the start-up adjustment phase, the following analyses were performed: $\mathrm{pH}$ (APHA, 1992), COD (APHA, 1992), TS and VS, alkalinity (AL) and volatile acidity (VA) (Silva, 1977).

\section{RESULTS AND DISCUSSION}

\section{First stage}

When HRT was 16.6 days the substrate presented $51.5 \mathrm{~g} \mathrm{~L}^{-1} \mathrm{O}_{2}$, resulting in an organic load of $3.1 \mathrm{~g} \mathrm{COD}$ $\mathrm{L}^{-1} \mathrm{~d}^{-1}, 2.2 \% \mathrm{TS}, 1, .6 \% \mathrm{VS}$ and $\mathrm{pH}$ between 5.5 and 6.0 (Table 2).
The COD, TS and VS values of the effluent increased with time, because the reactor was first filled with water, for temperature adjustment. Therefore, once the reactor started to be supplied with material, the effluent obtained consisted of water and biodigested manipueira, and this situation persisted until all the water was eliminated. By the end of this first HRT, the outlet $\mathrm{pH}$ was higher than that of the inlet, indicating that the methanogenic bacteria were consuming the organic acids produced by the acidogenic bacteria, and were, therefore, adapted to the manipueira organic load.

When HRT was 13.6 days, the substrate presented $27.2 \mathrm{~g} \mathrm{~L}^{-1} \mathrm{O}_{2}$, resulting in an organic load of 2.0 g COD L ${ }^{-1} \mathrm{~d}^{-1}, 4.19 \% \mathrm{TS}, 3.69 \% \mathrm{VS}$ and $\mathrm{pH}$ between 5.5 and 6.0 (Table 3). The optimal $\mathrm{pH}$ values for the growth of methanogenic bacteria is between 7.0 and 7.5, and these values were only found for the effluent on the first day and on the last two days of this HRT (Fernandes Jr., 1989; Lacerda, 1991; Sampaio, 1996; Barana, 2000).

As the organic load increased there was a greater production of organic acids by acidogenic bacteria (Table 3). At first, the methanogenic bacteria did not consume all the acid, causing a $\mathrm{pH}$ drop in the medium. However, as they adapted to the medium, which probably occurred on day $03 / 22$, they started to consume all the acid, making the medium more alkaline. The reduction in COD during this HRT, beginning on day 03/ 19 , remained between 58 and $70 \%$. Reductions in TS and VS, however, which were between $72 \%$ and $77 \%$ at the beginning, decreased to $42 \%$ and $58 \%$, respectively.

Results for reductions in COD, TS and VS did not show the same reduction and/or increasing behavior, probably because manipueira has solids in suspension that might have been retained inside the reactor. In addition, biomass is produced during digestion, which could exit the system in the effluent, increasing the sol-

Table 2 - Chemical oxygen demand (COD), total solids (TS), volatile solids (VS), pH and reduction in COD, TS and VS in the effluent from the first hydraulic retention time, (first stage).

\begin{tabular}{|c|c|c|c|c|c|c|c|}
\hline Collecting date & COD & Reduction in COD & TS & Reduction in TS & VS & Reduction in VS & $\mathrm{pH}$ \\
\hline & $\mathrm{g} \mathrm{L}^{-1} \mathrm{O}_{2}$ & - - & ---- & - $\%$ & - & - & \\
\hline 03/04 & 2.3 & 95 & 0.16 & 93 & 0.13 & 92 & 7.44 \\
\hline 03/05 & 5.2 & 88 & 0.41 & 81 & 0.34 & 78 & 4.85 \\
\hline 03/08 & 9.4 & 82 & 0.73 & 67 & 0.56 & 64 & 4.57 \\
\hline 03/09 & 10.2 & 80 & 0.99 & 55 & 0.79 & 49 & 4.47 \\
\hline $03 / 10$ & 10.2 & 80 & 1.30 & 41 & 0.95 & 39 & 4.50 \\
\hline 03/11 & 10.4 & 80 & 1.49 & 32 & 1.03 & 34 & 4.58 \\
\hline $03 / 13$ & 21.8 & 58 & 1.64 & 25 & 1.12 & 28 & 5.85 \\
\hline $03 / 14$ & 21.9 & 57 & 1.87 & 15 & 1.25 & 20 & 7.45 \\
\hline $03 / 16$ & 23.6 & 54 & 2.16 & 1.8 & 1.35 & 13 & 7.56 \\
\hline
\end{tabular}


Table 3 - Chemical oxygen demand (COD), total solids (TS), volatile solids (VS), pH and reduction in COD, TS and VS in the effluent from the second hydraulic retention time, (first stage).

\begin{tabular}{|c|c|c|c|c|c|c|c|}
\hline Collecting date & COD & Reduction in COD & $\mathrm{TS}$ & Reduction in TS & $\mathrm{VS}$ & Reduction in VS & $\mathrm{pH}$ \\
\hline & $\mathrm{g} \mathrm{L}^{-1} \mathrm{O}_{2}$ & 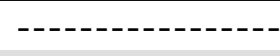 & ---- & -- \% - - & --- & 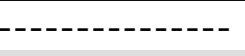 & \\
\hline $03 / 17$ & 20.2 & 25 & 1.17 & 72 & 0.84 & 77 & 6.87 \\
\hline $03 / 18$ & 15.6 & 42 & 1.06 & 75 & 0.75 & 80 & 6.39 \\
\hline $03 / 19$ & 8.8 & 68 & 1.13 & 73 & 0.83 & 77 & 5.88 \\
\hline $03 / 20$ & 8.4 & 69 & 1.24 & 70 & 0.75 & 80 & 5.82 \\
\hline $03 / 22$ & 9.5 & 65 & 1.35 & 68 & 0.95 & 74 & 5.26 \\
\hline $03 / 24$ & 8.1 & 70 & 1.90 & 55 & n. a. & n. a. & 5.42 \\
\hline $03 / 25$ & 9.8 & 64 & 1.75 & 58 & n. a. & n. a. & 5.43 \\
\hline $03 / 26$ & 8.6 & 68 & 1.88 & 55 & 1.25 & 66 & 5.55 \\
\hline $03 / 27$ & 8.8 & 68 & 1.91 & 54 & 1.33 & 64 & 5.76 \\
\hline $03 / 29$ & 11.3 & 58 & 2.67 & 36 & 1.86 & 50 & 6.00 \\
\hline $03 / 30$ & 11.5 & 58 & 2.29 & 45 & 1.57 & 57 & 5.98 \\
\hline $03 / 31$ & 10.8 & 60 & 2.36 & 44 & 1.55 & 58 & 6.20 \\
\hline $04 / 01$ & 10.6 & 61 & 2.41 & 42 & 1.54 & 58 & 6.73 \\
\hline $04 / 05$ & 11.2 & 58 & n. a. & n. a. & n. a. & n. a. & 7.18 \\
\hline
\end{tabular}

n. a.: not analyzed.

ids content. The reduction in COD, except for days 03/ 17 and $03 / 18$, remained practically constant, between $59 \%$ and $70 \%$; the reduction in TS and VS had a tendency to decrease from the beginning. Similarly, Fernandes Jr. (1995), studying an acidogenic reactor for manipueira treatment, did not find a relationship between the reductions in COD, TS and VS.

When HRT was equivalent to 11.6 days, the substrate presented $26.5 \mathrm{~g} \mathrm{~L}^{-1} \mathrm{O}_{2}$, resulting in an organic load of $2.3 \mathrm{~g} \mathrm{COD} \mathrm{L}^{-1} \mathrm{~d}^{-1}, 4.87 \% \mathrm{TS}, 4.31 \% \mathrm{VS}$ and $\mathrm{pH}$ between 5.5 and 6.0. The COD, TS and VS of the effluent decreased from the beginning of this HRT (Table 4). The outlet $\mathrm{pH}$ had a tendency to decrease, as it reached values near 4.0, probably indicating that the methanogenic bacteria were inhibited, since they operate by transforming the acids produced by the acidogenic bacteria into methane, neutralizing the medium and increasing the $\mathrm{pH}$ (Nogueira, 1986). For this HRT, the COD reduction values were practically constant, around $60 \%$. The COD in the effluent ranged from 9.9 to $10.7 \mathrm{~g} \mathrm{~L}^{-1} \mathrm{O}_{2}$.

The reductions in TS and VS also remained practically constant, and their lowest values occurred on the last day of this HRT, with $38 \%$ and $48 \%$ of reduction in TS and VS, respectively. With the $\mathrm{pH}$ of the effluent decreasing every day, indicating predominantly the activity of acidogenic bacteria, a decision was made to add a methanobacteria-rich inoculum to the digester. Bovine manure, diluted to $17 \% \mathrm{TS}$ and at an $\mathrm{pH} 8.03$, was added. This was the same inoculum used by Lacerda (1991), who worked with a methanogenic anaerobic filter for manipueira treatment. However, while studying the acidogenic stage in a two-stage anaerobic reactor Fernandes Jr. (1995), used rumen fluid as inoculum, and concluded that it was suitable for the manipueira acidogenesis process, since it provides microorganisms capable of accomplishing carbohydrate hydrolysis and fermentation, as confirmed through the microbiological study of the effluent.

Even with a low effluent $\mathrm{pH}$, the level of COD reduction was maintained practically constant during this stage, around $60 \%$. This was caused mainly by the acidogenesis process in the substrate, part of the organic matter being released in the form of $\mathrm{CO}_{2}$. Fernandes Jr. (1995), working with the acidogenic stage in a phase separation anaerobic digester, obtained an average reduction in COD of $23.5 \%$ for all HRTs. Sampaio (1996), in a viability study of the anaerobic manipueira treatment process with a two-stage system, obtained acidogenesis reductions up to $51 \%$. Cohen (1979), cited by Sampaio (1996), obtained a mean reduction in total organic carbon ranging in $39 \%$ with glucose acidogenesis.

When the HRT was 9.6 days, the substrate presented $28.4 \mathrm{~g} \mathrm{~L}^{-1} \mathrm{O}_{2}$, resulting in an organic load of 2.9 g COD L $\mathrm{d}^{-1}, 4.87 \% \mathrm{TS}, 4.31 \% \mathrm{VS}$ and $\mathrm{pH}$ between 6.0 and 6.5. The $\mathrm{pH}$ values of the effluent showed a tendency to increase from the beginning of this HRT study, indicating a possible readaptation of the methanobacteria to the substrate (Table 5). The reduction in COD was maintained practically constant, with a $60 \%$ average, corresponding to a mean COD of $10.1 \mathrm{~g} \mathrm{~L}^{-1} \mathrm{O}_{2}$ at the outlet. The observed TS and VS reductions were on average $47.5 \%$ and $63.5 \%$, respectively. 
Table 4 - Chemical oxygen demand (COD), total solids (TS), volatile solids (VS), pH and reduction in COD, TS and VS in the effluent from the third hydraulic retention time, (first stage).

\begin{tabular}{|c|c|c|c|c|c|c|c|}
\hline Collecting date & COD & Reduction in COD & TS & Reduction in TS & VS & Reduction in VS & $\mathrm{pH}$ \\
\hline & $\mathrm{g} \mathrm{L}^{-1} \mathrm{O}_{2}$ & --------------- & ---- & - $\%$--.-- & ---- & - & \\
\hline $04 / 06$ & 9.9 & 62 & 2.45 & 47 & 1.74 & 60 & n. a. \\
\hline $04 / 09$ & 10.8 & 59 & 2.81 & 42 & 1.97 & 54 & 6.56 \\
\hline $04 / 10$ & 9.9 & 62 & 2.45 & 47 & 1.71 & 60 & 6.82 \\
\hline $04 / 12$ & 9.9 & 62 & 2.02 & 58 & 1.45 & 66 & 6.16 \\
\hline $04 / 13$ & 10.0 & 62 & 2.35 & 52 & 1.69 & 60 & 5.74 \\
\hline $04 / 14$ & 10.1 & 62 & 2.27 & 53 & 1.50 & 65 & 5.72 \\
\hline $04 / 15$ & 10.0 & 62 & 2.02 & 58 & 1.38 & 68 & 5.68 \\
\hline $04 / 16$ & 10.1 & 62 & 2.12 & 56 & 1.42 & 67 & 5.52 \\
\hline $04 / 20$ & 10.6 & 60 & 2.35 & 52 & 1.63 & 62 & 5.16 \\
\hline $04 / 21$ & 10.4 & 61 & 2.56 & 47 & 1.87 & 57 & 4.58 \\
\hline $04 / 22$ & 10.2 & 62 & 2.71 & 44 & 1.98 & 54 & 4.39 \\
\hline $04 / 23$ & 10.7 & 59 & 3.00 & 38 & 2.21 & 49 & 4.29 \\
\hline $04 / 26$ & 10.2 & 61 & 3.09 & 36 & 2.29 & 47 & 4.06 \\
\hline $04 / 27$ & 10.7 & 60 & 3.15 & 35 & 2.43 & 44 & 4.04 \\
\hline $04 / 29$ & 10.7 & 59 & 2.66 & 45 & 2.11 & 51 & 4.07 \\
\hline 05/01 & 10.7 & 60 & 3.01 & 38 & 2.24 & 48 & 4.06 \\
\hline
\end{tabular}

n. a.: not analyzed.

Table 5 - Chemical oxygen demand (COD), total solids (TS), volatile solids (VS), $\mathrm{pH}$ and reduction in COD, TS and VS in the effluent from the fourth hydraulic retention time.

\begin{tabular}{|c|c|c|c|c|c|c|c|}
\hline Collecting date & COD & Reduction in COD & TS & Reduction in TS & VS & Reduction in VS & $\mathrm{pH}$ \\
\hline & $\mathrm{g} \mathrm{L}^{-1} \mathrm{O}_{2}$ & 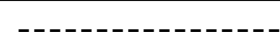 & ---- & - $\%$ - - & ---- & 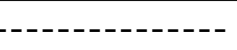 & \\
\hline $06 / 02$ & 10.8 & 62 & 2.66 & 45 & 1.62 & 62 & 4.30 \\
\hline $06 / 07$ & 11.0 & 61 & 2.63 & 46 & 1.65 & 62 & 4.43 \\
\hline $06 / 10$ & 10.8 & 62 & 2.51 & 48 & 1.44 & 66 & 4.45 \\
\hline $06 / 12$ & 10.4 & 63 & 2.39 & 51 & 1.23 & 71 & 4.59 \\
\hline $06 / 14$ & 11.3 & 60 & 2.80 & 42 & 1.51 & 65 & 4.10 \\
\hline $06 / 15$ & 11.0 & 61 & 2.72 & 44 & 1.87 & 57 & 4.68 \\
\hline $06 / 17$ & 10.9 & 62 & 2.70 & 44 & 1.86 & 57 & 4.72 \\
\hline $06 / 18$ & 10.8 & 62 & 2.36 & 51 & 1.68 & 61 & 4.64 \\
\hline $06 / 21$ & 11.5 & 59 & 1.97 & 59 & 1.41 & 67 & 5.35 \\
\hline $06 / 26$ & 11.2 & 60 & 2.28 & 53 & 1.24 & 71 & 5.05 \\
\hline $07 / 14$ & 10.7 & 62 & 2.74 & 44 & 1.85 & 57 & 5.62 \\
\hline $07 / 15$ & 10.5 & 63 & n.a. & - & n.a. & - & 5.51 \\
\hline $07 / 16$ & 11.1 & 61 & n.a. & - & n.a. & - & 5.42 \\
\hline $07 / 21$ & 11.2 & 60 & 2.74 & 44 & 1.47 & 66 & 6.08 \\
\hline
\end{tabular}

n.a.: not analyzed.

\section{Second stage}

During the second organic load, the reduction in COD and volatile solids remained practically constant, with a mean reduction of $71 \%$ and $80 \%$, respectively (Table 6). The reduction in total solids remained constant at $63 \%$ for the third and fourth HRTs.

TS content presented a decrease from $57 \%$ to $48 \%$, and in VS content, from $80 \%$ to $68 \%$, for the third organic load as compared to the second, while the COD was practically the same, showing a reduction of $72 \%$, on average.

When the fourth organic load is compared to the third, a decrease in COD reduction can be observed, from $72 \%$ to $3 \%$, on average, in the last HRT (sampled on 11/ 03 ). With regard to the total and volatile solid contents, the reduction was $43 \%$ and $83 \%$, respectively. 
Table 6 - Chemical oxygen demand (COD), total solids (TS), volatile solids (VS), and reduction in COD, TS and VS in the effluent from organic loads during the second stage.

\begin{tabular}{|c|c|c|c|c|c|c|c|}
\hline \multicolumn{8}{|c|}{ First organic load } \\
\hline HRT & Sampling date & COD & Reduction in COD & TS & Reduction in TS & VS & Reduction in VS \\
\hline & & $\mathrm{g} \mathrm{L}^{-1} \mathrm{O}_{2}$ & - & $\ldots$ & - $\%$ - & $\cdots$ & - \\
\hline $2^{\text {nd }}$ & $09 / 05$ & 2.22 & 0 & - & 0 & - & - \\
\hline $3^{\text {rd }}$ & 09/09 & 1.58 & 18 & 0.50 & 0 & 0.39 & 0 \\
\hline $4^{\text {th }}$ & $09 / 12$ & 1.03 & 46 & 0.28 & 0 & 0.08 & 67 \\
\hline \multicolumn{8}{|c|}{ Second organic load } \\
\hline $2^{\text {nd }}$ & $09 / 20$ & 0.99 & 71 & 0.19 & 46 & 0.05 & 84 \\
\hline $3^{\text {rd }}$ & $09 / 27$ & 1.01 & 70 & 0.13 & 63 & 0.07 & 78 \\
\hline $4^{\text {th }}$ & $10 / 01$ & 1.00 & 71 & 0.13 & 63 & 0.07 & 78 \\
\hline \multicolumn{8}{|c|}{ Third organic load } \\
\hline $2^{\text {nd }}$ & $10 / 08$ & 544 & 83 & 0.20 & 62 & 0.14 & 71 \\
\hline $3^{\text {rd }}$ & $10 / 15$ & 1103 & 66 & 0.26 & 51 & 0.17 & 64 \\
\hline $4^{\text {th }}$ & $10 / 19$ & 1121 & 66 & 0.37 & 30 & 0.15 & 69 \\
\hline \multicolumn{8}{|c|}{ Fourth organic load } \\
\hline $2^{\text {nd }}$ & $10 / 26$ & 8.01 & 18 & 0.35 & 47 & 0.13 & 78 \\
\hline $3^{\text {rd }}$ & $10 / 30$ & 8.01 & 18 & 0.38 & 42 & 0.09 & 85 \\
\hline $4^{\text {th }}$ & $11 / 03$ & 9.56 & 3 & 0.40 & 39 & 0.08 & 87 \\
\hline
\end{tabular}

\section{Alkalinity, pH and volatile acidity for four organic loads during the second stage}

Even though the substrate $\mathrm{pH}$ was corrected to values between 5.5 and 6.0 , the effluent $\mathrm{pH}$ remained between 4.46 and 5.23, indicating that in this stage acidogenic bacteria were probably predominant. The lowest $\mathrm{pH}$ at the outlet occurred for the first organic load, and the highest for the last load, probably indicating methanobacteria recovery, as they began to consume the organic acids produced by the acidogenic bacteria, decreasing volatile acidity and increasing alkalinity (Table 7).

The $\mathrm{pH}$ at the outlet was expected to be about neutral, which would indicate greater activity of methanogenic bacteria. However, it remained at similar values for all organic loads under study, i.e., around 5.0. Even though the ideal effluent $\mathrm{pH}$, near 7.0, was not attained, which reveals low methanobacteria activity, significant reduction values for the organic load in the residue were observed. The significant reduction in soluble COD obtained in the corresponding study during the acidogenic stage of the anaerobic process could have occurred because of the formation and release of $\mathrm{CO}_{2}$ by fermentative and acetogenic bacteria (Sampaio, 1996).

Barana (1996) obtained 66\% reduction in COD for an inlet organic load of $0.33 \mathrm{~g} \mathrm{COD} \mathrm{L}^{-1} \mathrm{~d}^{-1}$; there was a $92 \%$ reduction for a $3.75 \mathrm{~g} \mathrm{COD} \mathrm{L}^{-1} \mathrm{~d}^{-1}$ load, but with heavier loads the reduction in COD decreased, reaching $55 \%$ with a $8.48 \mathrm{~g} \mathrm{COD} \mathrm{L}^{-1} \mathrm{~d}^{-1}$ load.

The volatile acidity/alkalinity ratio is distinctive in a two-stage system anaerobic process, and supposedly higher than 1 at acidogenesis, since at this stage higher concentration of acids is obtained, because of the presence of larger amounts of acidogenic bacteria (Sampaio, 1996).
The ratio between volatile acidity/alkalinity would be important as indication that the digester is or is not stable. Values close to 0.4 would indicate instability and values above 0.8 would warn that the reactor is collapsing (Souza, 1984, quoted by Barana 1996). According to Silva (1977) this ratio should be between 0.06 and 0.2. Hirata (1999), suggests a range between 0.1 and 0.3 as optimal values for this ratio. Working with twostage digesters for manipueira treatment, Barana (2000) obtained VA/AL values between 0.8 and 1.4 for the methanogenic stage, and even with such values the COD reduction rates were between $49.33 \%$ and $85.61 \%$. During the second stage, the higher COD reduction, $80 \%$, was obtained with VA/AL values about 2.58 . And with the lowest VA/AL ratio, 1.76, there was the lowest COD reduction, 13\% (Tables 6 and 7).

Since the velocity of biomass formation depends on substrate concentration, up to a certain limit, the larger the organic load at the inlet, i.e., substrate, the higher the velocity of multiplication, both for acidogenic and methanogenic bacteria. Therefore, even though larger amounts of organic acids were produced, they could have been consumed by the methanobacteria.

The instability in the process of anaerobic digestion of manipueira occurs because of the characteristics of the residue; since it contains a considerable amount of easily-fermentable carbohydrates, the acid stage can occur very rapidly as compared to the methanogenic stage, leading to an accumulation of volatile organic acids (Fernandes Jr. \& Takahashi, 1994). One strategy that can be utilized to control this fact is to physically separate the stages, i.e., to perform the acid and methanogenic digestion stages in individual and separate reactors, aiming to operate them with higher efficiency and stability. 
Table 7 - pH values for each hydraulic retention time (HRT), volatile acidity (VA), alkalinity (AL) and VA/AL ratio of the effluents for four organic loads during the second stage of the experiment.

\begin{tabular}{|c|c|c|c|c|c|c|}
\hline Organic Load & HRT & Effluent $\mathrm{pH}$ & Mean effluent $\mathrm{pH}$ & Volatile acidity & Alkalinity & $\mathrm{VA} / \mathrm{AL}$ \\
\hline \multirow{4}{*}{ First } & & & & $\mathrm{mg} \mathrm{CH}_{3} \mathrm{COOH} \mathrm{L}{ }^{-1}$ & $\mathrm{mg} \mathrm{CaCO}_{3} \mathrm{~L}^{-1}$ & \\
\hline & $2^{\text {nd }}$ & 4.49 & 4.60 & 5366 & 889 & 6.03 \\
\hline & $3^{\text {rd }}$ & 4.46 & & & & \\
\hline & $4^{\text {th }}$ & 4.98 & & & & \\
\hline \multirow{3}{*}{ Second } & $2^{\text {nd }}$ & 4.88 & 4.90 & 1654 & 642 & 2.58 \\
\hline & $3^{\text {rd }}$ & 4.94 & & & & \\
\hline & $4^{\text {th }}$ & 4.90 & & & & \\
\hline \multirow{3}{*}{ Third } & $2^{\text {nd }}$ & 4.93 & 5.00 & 2737 & 1356 & 2.02 \\
\hline & $3^{\text {rd }}$ & 5.08 & & & & \\
\hline & $4^{\text {th }}$ & 5.14 & & & & \\
\hline \multirow{3}{*}{ Fourth } & $2^{\text {nd }}$ & 5.06 & 5.10 & 2744 & 1555 & 1.76 \\
\hline & $3^{\text {rd }}$ & 5.11 & & & & \\
\hline & $4^{\text {th }}$ & 5.23 & & & & \\
\hline
\end{tabular}

\section{REFERENCES}

AMERICAN PUBLIC HEALTH ASSOCIATION. Standard methods for the examination of water and wastewater. 18 ed. Washington: APHA, 1992.

ARMENANTE, P.M. Biotreatment of industrial and hazardous waste. In.: LEVIN, M. A.; GEALT, M.A. New York: McGraw-Hill, 1993.

BARANA, A.C. Estudo de carga de manipueira em fase metanogênica em reator anaeróbio de fluxo ascendente e leito fixo. Botucatu: UNESP/ FCA, 1996. 80p. (Dissertação - Mestrado)

BARANA, A.C. Avaliação de tratamento de manipueira em biodigestores fase acidogênica e metanogênica. Botucatu: UNESP/FCA, 2000. 95p. (Tese - Doutorado)

DAMASCENO, S. Manipueira como substrato para desenvolvimento de Geotrichum fragans. Botucatu: UNESP/FCA, 1998. 117p. (Tese Doutorado)

FERNANDES JR., A. Ocorrência de instabilidade e forma de seu controle na digestão anaeróbia de manipueira em reator de bancada de mistura completa. Botucatu: UNESP/FCA, 1989. 118p. (Tese - Mestrado)

FERNANDES JR., A.; TAKAHASHI, MRefe. Tratamento da manipueira por processos biológicos - aeróbio e anaeróbio. In: CEREDA, M. P. Resíduos da industrialização da mandioca. São Paulo: Paulicéia, 1994, p.133-150.

FERNANDES JR., A . Digestão anaeróbia de manipueira com separação de fases: cinética da fase acidogênica. Botucatu: UNESP/FCA, 1995. 139p. (Tese - Doutorado)

FIORETTO, R.A. Efeito da manipueira aplicada em solo cultivado com mandioca (Manihot esculenta, Crantz). Botucatu: UNESP/FCA, 1985. 112p. (Dissertação - Mestrado)

HIRATA, Y.S. Coleta, preservação e caracterização de efluentes. Florianópolis: UFSC, Faculdade de Engenharia Química e de Alimentos, 1999.

KUBIAK, C.; DUBUIS, T. Valorização dos objetos e dos efluentes agrícolas, industriais e domésticos. In: SCRIBAN, R.; ARNAUD, A.; PEREIRA, M.E.G.G. Biotecnologia. São Paulo: Manole, 1985. p. 401-421.

LACERDA, T.H.M. Estudo cinético da fase metanogênca de substrato de manipueira. Botucatu: UNESP/FCA, 1991. 114p. (Tese - Doutorado)

LETTINGA, G.; HULSHOFF POL, L.W. UASB - Process design for various types of wastewaters. Water Science Technology, v.24, p.87-107, 1991.

MENEZES, T.J.B. de. Mandioca, resíduos e subprodutos para produção de biomassa protéica. In: CEREDA, M.P. Resíduos da industrialização da mandioca. São Paulo: Paulicéia, 1994. p.101-108.
NOGUEIRA, L.A H. Biodigestão: a alternativa energética. São Paulo: Nobel, 1986. 93p.

PONTE, J.J. da; FRANCO, A. Manipueira, um nematicida não convencional de comprovada potencialidade. Nematologia Brasileira, v.7, p.21-25, 1983.

PONTE, J.J. da; FRANCO, A.; SANTOS, J.H.R. Eficiência da manipueira no controle de duas pragas da citricultura. In: CONGRESSO BRASILEIRO DE MANDIOCA, 7., Recife, 1992. Anais. Recife: Sociedade Brasileira de Mandioca, 1992. p.59.

PONTE, J. J. da Uso da manipueira como insumo agrícola: defensivo e fertilizante. In: CEREDA, M. P. Manejo, uso e tratamento de subprodutos da industrialização da mandioca. São Paulo: Fundação Cargill, 2001. p.80-95.

SAMPAIO, B.M.L. Viabilidade do processo de tratamento anaeróbio do resíduo da industrialização da mandioca em sistema de duas fases. Maringá: UEM, 1996. 176p. (Dissertação - Mestrado)

SANTOS, C.F.C.; PASTORE, G.M.; DAMASCENO, S.; CEREDA, M. P. Produção de biosurfactantes por linhagens de Bacillus subtilis utilizando manipueira como substrato. Revista Ciência e Tecnologia de Alimentos, v.33, p. 157-161, 2000.

SENA, E.S.; PONTE, J.J. da. A manipueira no controle da Meloidoginose da cenoura. Nematologia Brasileira, v.6, p.95-8, 1982.

SILVA, M.O.S.A. Análises físico-químicas para o controle de estações de tratamento de esgotos. São Paulo: CETESB, 1977. 226p.

SOUZA, M.E. Fatores que influenciam a digestão anaeróbia. Revista DAE, v.44, p.88-94, 1984.

STRONACH, S.M.; RUDD, T.; LESTER, J.N. Start-up of anaerobic bioreactors on high strength industrial wastes. Biomass, v.13, p.173$197,1987$.

WOSIACKI, G.; FIORETTO, A.M.C.; CEREDA, M.P. Utilização da manipueira para produção de biomassa oleaginosa. In: CEREDA, M.P. Resíduos da industrialização da mandioca. São Paulo: Paulicéia, 1994. p.151-161.

$\overline{\text { Received October }}$ 26, 2001 